\title{
Shingon Risshū: Esoteric Buddhism and Vinaya Orthodoxy in Japan
}

\author{
Klaus PINTE
}

Shingon Risshū 真言律宗 (lit. 'Mantra Vinaya School') designates the Japanese Buddhist order of Saidaiji (Saidaijiryū 西大寺流) in Nara 奈良 that emerged from the 'precepts restoration movement' (kairitsu fukkō undō 戒律復興運動) initiated by Eison 㪍尊 (1201-1290; also Eizon) et al. around 1238. (Groner 2005: 215; cf. infra) The distinctive twofold appellation 'Shingon Risshū' hints at the synthesis of Shingon doctrine and ritual with the praxis and ceremonial of monastic discipline as propagated in the Japanese 'Vinaya School' or Risshū 律宗. (Quinter 2007: 437. On the origins and establishment of Risshū in Japan, see: Hankó 2003: esp. 327ff.; for genealogies, ibid. 357-358)

Although very little is known about the first Buddhist communities on the Japanese archipelago (Hankó 2003: 329-333), early Nara period (710-784/94) hieratical officiates seem to have been regulated by - and primarily conducted for the welfare of - the state. The procedure had more to do with evaluating a candidate's diligence in chanting sütras or performing nationprotection ceremonies, than with his/her vowing to uphold a certain set of disciplinary rules in front of a quorum of ten—or in remote areas five-legitimately ordained monks, three learning masters and two or seven witnesses, as the 'orthodox' method prescribed. (Hankó 2003: 333) Aside the official sacerdotal examination system, there were also self-ordained priests/priestesses

PINTE Klaus, Shingon Risshū, version of Thursday, November 27, 2008, p. - 1 - 
or 'monastics who liberated themselves' (jidosō 私度僧). (Groner 1984: 5-6; for contemporary self-ordinations or 'vowing to keep the precepts on your own accord', i.e. jisei-jukai 自誓受戒, and their textual foundation, see: Hankó 2003: 332-334, esp. *2; Yamabe 2005; on early ordinations in Japan, see: Hankó 2003: 328ff.)

In 733 , however, the court sent out two men in order to request Chinese masters to come to Japan and perform legitimate ordinations according to the regulations of the Sifunlü 四分律 (Shibunritsu), further: SBR) [T. 1428]. ${ }^{1}$ (Groner 1984: 7) Their invitation was accepted by the reputed vinaya master (risshi 律師) Jianzhen 鑑真 (Ganjin, 688-763), who reached Japan in 753/4. (Ueda 1939: 120; Hankó 2003: 346; on Ganjin, see: ibid.: 341-352). He introduced the SBR-interpretation of Daoxuan 道宣 (596-667) or the Nanshan Vinaya School (Nanshan Lüzong 南山律宗), and conferred the 'full precepts' (gusokukai 具足戒) of the continental tradition upon Japanese priests who renounced their previous 'unorthodox' initiations, and thus became the first full-fledged formally and properly ordained monastics on Japanese soil. Jianzhen erected an Ordination Platform Hall (Kaidan'in 戒壇院, also Kaidandō 戒壇堂) at Tōdaiji 東大寺 (Nara) in 755, which became the center for official ordinations. ${ }^{2}$ (Groner 1984: 8-9)

\footnotetext{
${ }^{1}$ This Chinese translation of the Dharmaguptaka-vinaya had been accepted as the only valid scriptural authority for monastic ordination practice throughout China almost two decades earlier. (Heirman 2002: 422; Heirman 2007: 195; André Bareau, cited in McRae 2005: 70)

${ }^{2}$ For six years the Tōdaiji Kaidan'in was the only permanent ordination platform on Japanese soil, but since empress Kōken 孝謙 (r. 749-758, alias Shōtoku 称徳, r. 764-770) ordered the erection of two additional precept platforms in 761, it became known as the 'central platform' or chūō kaidan 中央戒壇, while at Yakushiji 薬師寺 in Shimotsuke 下野 (Tochigi) there was an 'eastern platform' or tōkaidan 東戒壇 and at Kannonji 観音寺 in Chikuzen 筑前
}

PINTE Klaus, Shingon Risshū, version of Thursday, November 27, 2008, p. - 2 - 
However, as in China where Mahāyānists took an additional set of precepts as a supplement to the SBR, Jianzhen also conferred the bodhisattva-síla (bosatsukai 菩薩戒) of the Fanwangjing 梵網經 (Bonmōkyō; further BMK [T. 1484]) upon the Japanese candidates as a 'separate ordination' (betsuju 別受). ${ }^{3}$ (Groner 1979: 26; Unno 1994: 29; Abe 1999: 47-49; Groner 2005: 214) Jianzhen's establishment of a legitimate ordination system gave him the reputation of the founder of Risshū, which from 759 onwards had its headquarters in Tōshōdaiji 唐招提寺. (Ueda 1939: 120; Hankó 2003: 13-14, n. 39-40)

Although ordinations soon became purely pro forma (Faure 1998: 173), the system of separate SBR and BMK ordinations seems to have remained the standard format in the Heian period (784/94-1185) at least until 822. In that year, just some days after the death of Saichō 最澄 (767-822), Tendai 天台 priests were legally permitted to ordain so-called 'Mahāyāna bodhisattva monks' (daijō bosatsusō 大乗菩薩僧), the procedure of which was exclusively based on the 'perfect and sudden Mahāyāna precepts' (daijō endonkai 大乗圓頓戒) of the BMK, and was

(Fukuoka) a saikaidan 西戒壇 or 'western platform’. (Eliot 2005: 232. On ordination platforms in India and China, see: McRae 2005: 75ff.)

${ }^{3}$ Traditionally the alleged translation of the Sanskrit Brahmajāla-sūtra or the tenth chapter of the Bodhisattvaśīlasūtra attributed to Kumārajīva (344-413) in 406, but nowadays accepted as a Chinese forgery. By the end of the fifth century, the second fascicle of the BMK circulated as a so-called Bodhisattva-prātimokșa (Pusa jieben; Bosatsu kaihon 菩薩戒本), which formed the basis for the Mahāyānist code in East Asia. (On the term bodhisattvaprātimokșa, see: Malalasekera 1972: 240-246; For a brief discussion on the apocryphal origins of the BMK, see Hankó 2003: 108-110. For an annotated German translation, see: Ibid.: 125-181, and 182-185 for an overview. For a complete French translation, cf. De Groot 1967. For further reference, see Groner 1990: esp. 251-257; Gombrich 1998: 52-53; Yamabe 2005).

PINTE Klaus, Shingon Risshū, version of Thursday, November 27, 2008, p. - 3 - 
performed on a new Tendai-exclusive precepts platform at Enryakuji 延暦寺 atop Hieizan 比㕡 山. (Ueda 1939: 119; Groner 1984: 162; Groner 2005: 214) Thus, within a century after the introduction of the vinaya into Japan, Tendai priests abandoned the continental ordination procedure and rejected the Tōdaiji SBR-ordination as conditio sine qua non to enter the monastic order.

In the same year, Kūkai 空海 (774-835) received imperial consent to erect an Abhișeka Hall (Kanjōdō 灌頂堂, also Shingon'in 真言院) in front of the Great Buddha Hall (Daibutsuden 大仏殿) at Tōdaiji. (Abe 1999: 53) As is apparent from his dying instructions (Kōnin no Goyuikai 弘仁の御遺誡), Kūkai instructed Shingon priests to “strictly adhere to both the exoteric and esoteric precepts (ken-mitsu ni kai 顯密二戒), ${ }^{4}$ and to purify themselves.” (KDZ, Vol. II: 861; quoted in Ueda 1939: 141) He admonished them: "if you purposely violate [these precepts], you are not a disciple of the Buddha [...] nor are you my disciple". (KDZ, Vol. II: 862, trans. Groner 2005: 211. For Kūkai, cf. supra......) However, adherence to the vinaya was again soon in decline, and it was only in the Kamakura (1185-1333) period that Kūkai's admonition to strictly observe the monastic code inspired Buddhist prelates to initiate a 'precepts restoration

\footnotetext{
${ }^{4}$ The 'esoteric precepts' (mitsukai 密戒) are also called ‘samaya precepts' (sanmayakai 三昧耶戒), and according to Kükai comprise four vows centered on the aspiration to attain enlightenment (cf. KDZ, II: 150-151, Engl. trans. Hakeda 1972: 94-95), while he included in the 'exoteric precepts' (kenkai 顯戒) the disciplinary codes of the SBR and BMK. (For Kūkai's precepts view, see Ueda 1933; for the origins of the sanmayakai, cf. Tomabechi 1990) The history of the order in which the respective SBR, BMK and samaya precepts are bestowed during the ordination process is addressed in my forthcoming dissertation (expected 2012).
}

PINTE Klaus, Shingon Risshū, version of Thursday, November 27, 2008, p. - 4 - 
movement' in order to revive the SBR ordination tradition and to restore the vinaya 'orthodoxy' of Jianzhen's Risshū. ${ }^{5}$

Although Jippan 實範 (1089?-1144; also Jitsuhan) from Nakagawa 中川 (Nara) is considered the trailblazer of the Shingon Risshū movement, Kakujō 覺盛 (1194-1249) of Tōshōdaiji (Nara) and especially Eison of Saidaiji are perhaps its most famous prelates. (For Eison's biography, see: Groner 2005: 210-221) While Shingon Risshū in Nara became known as the 'Southern School' or 'Vinaya School of the Southern Mountains' (Nanzan Risshū 南山律宗) and became the dominant trend, there was also a 'Northern School' (Hokushū 北宗), centred in Kyōto. (Faure 1998: 173-4) One of the latter's most renowned representatives is Shunjō 俊秀 (1166-1227) of Sennyūji 泉涌寺. (Groner 2005: 215) Other Kamakura period (1185-1333)

\footnotetext{
${ }^{5}$ Therefore, while Shingon Risshū is narrowly defined as a specific 'school' (shū 宗), the term Shingon-ritsu 真言律 designates both the Shingon precepts interpretation of Kükai, as well as the amalgam of movements for the revival of monastic discipline that was preached by Shingonshū trained - or at least affiliated - priests. (MD 1277c, s.v. Shingon-ritsu; Ueda 1939: 120-121) In this broader sense, Shingonritsu has been described as "inside being the secret practice of bodhisattvas, but outside appearing as the revealed śrāvaka path" (Ueda 1939: 119). Shingon Risshū preaches the 'orthodox' way of employing the SBR-codex, both during ecclesiastic initiation as in daily monastic life, while at the same time adhering to the BMK bodhisattva-síla and samaya precepts, as well as to abiding by the teachings of Shingon. (Ueda 1939: 141; For Shingon Risshū lineages, see Ueda 1939: 130-132) The attempts to restore vinaya 'orthodoxy' were in large extent a reaction against such figures as Shinran 親㝈 (11731262), the founder of the True Pure Land School (Jōdo Shinshū 浄土真宗, also Shinshū 真宗) who caused mainstream Buddhists to virtually abandon every form of disciplinary rule. (Ueda 1939: 119. On Shinran, see e.g. Hirota 1989; Nasu 2006. For Shinshū, see e.g. Yamamoto 1963; Dobbins 1989; Porcu 2008) Next to vinaya restoration movements, there were also Kamakura period attempts to revive the bodhisattva precepts (Faure 1998: 173-4). Due to space limitations, these developments will be discarded.
}

PINTE Klaus, Shingon Risshū, version of Thursday, November 27, 2008, p. - 5 - 
Shingon Risshū representatives are Gedatsu 解脱 alias Jōkei 貞慶 (1155-1213) from Kasagi 笠置 (to the northeast of Nara), Myōe 明惠 (1173-1232) from Toga-no-o 栂尾 in Yamashiro 山城 (Kyōto), and Eison's disciple Ryōkan 良観 alias Ninshō 忍性 (1217-1303) from Gokurakuji 極 楽寺 (Kamakura). Eison and Ninshō are particularly known for their contributions to Buddhist social aid. ${ }^{6}$ (Quinter 2007. On Myōe, see Unno 1998, 2004, 2006: 129ff; Abe 2006) It is noteworthy that, just as during the period prior to Jianzhen, Eison and Kakujō saw themselves compelled to self-ordinations, which in contrast to the Nara tradition of separate SBR and BMK ordinations were performed as a single 'comprehensive ordination' (tsüju 通受) before a Buddha statue (honzon 本尊) in the hope of re-establishing a legitimate Dharma lineage. (Groner 2005: 212ff.) This meant "a dramatic break from the tradition espoused by Japanese vinaya masters from Jianzhen, through Jippan and Jōkei" and "none of these [former] vinaya masters would have allowed the use of self-ordinations to ordain monks" (Groner 2005: 213-214).

Nevertheless, adherence to the precepts soon declined again, and it took about three and a half centuries before at the beginning of the Edo period (1603-1867) renewed precepts restoration attempts emerged. Myōnin 明忍 (1576-1610), who together with his disciples Yūzon 友尊 (n.d.) and Eun 慧雲 (n.d.) took self-initiation at Byōdōshin'ō-in 平等心王院 on Makiozan 槇尾山 in Yamashiro in 1602, initiated this movement and subsequently transformed Makiozan into a 'practice hall (also: manda) for precepts restoration' (ritsu saikō dōjō 律再興道場). (Ueda 1939: 121-122) The Makiozan faction (Makiozanha 梖尾山派) inspired other Edo period monks to

\footnotetext{
${ }^{6}$ Except from Myōe and Jōkei, all these precepts revivers were monks with a clear Shingon affiliation. (Ueda 1939: 120-121)
}

PINTE Klaus, Shingon Risshū, version of Thursday, November 27, 2008, p. - 6 - 
found other vinaya-vihäras (ritsuen 律園) or temples where monks were trained in accordance to the SBR. For instance, Yoshinaga 良永 (1585-1647) returned to his birthplace Kōyasan in 1619 after being initiated by Eun, and founded Shinbessho Entsūji 眞別處圓通寺, which became the headquarters of Kōyasan Risshū. Yoshinaga's pupil, Kaien Ekū 快圓惠空 (d. 1712), revived Shinhōji 神鳳寺 on Ōtorizan 大鳥山 in Izumi 和泉, and Jinin Emyō 慈忍慧猛 (1615-1675), Myōnin's second generation disciple, restored Yachūji 野中寺 in Kawachi 河内 (Kashū 河州). Thus, Makiozan, Ōtorizan and Yachūji became the centers of SBR studies and are known as the 'three vinaya training temples' (ritsu no san sōbō 律の三僧坊). Because their founders were Shingon affiliated monks, these temples are also called the 'three branches of Shingon Risshū' (Shingon Risshū no san ha 真言律宗の三派). However, those who succeeded them later considered themselves closer to Risshū, and are therefore categorized as Shibun Risshū 四分律宗 (Dharmaguptaka-vinaya School) or Shibunha 四分派 (Dharmaguptaka faction). (Ueda 1939: 122)

Some Edo period monks went even a step further and established their own forms of Shingon Risshū. Jōgon 淨嚴 (1639-1702, ordained by Kaien), for instance, sought to establish a samgha according to the orthodox teachings of the Buddha, and preached the 'Dharma-Accordant Mantra Vinaya' (Nyohō Shingon Ritsu 如法真言律), which also aimed to restore the SBR precepts. In 1677 he founded Enmeiji 延命寺 in Kawachi and, relying on the patronage of shōgun Tokugawa Tsunayoshi 徳川綱吉 (1646-1709), established Reiunji 靈雲寺 on Hōrinzan 寶林山 in Yushima 湯島 (Edo) in 1691. The Reiun branch (Reiunha 靈雲派) of Nyohō Shingon Ritsu employs the SBR and is still extant today. (Ueda 1939: 123) On the other hand, Jiun 慈雲 (1718-1804), who succeeded the Yachüji-lineage, is the founder of what is known as the 'Correct PINTE Klaus, Shingon Risshū, version of Thursday, November 27, 2008, p. - 7 - 
Dharma Vinaya' (Jōbō Ritsu 正法律), which he proclaimed in 1756. Thirty years later, Kōkiji 高 貴寺 in Kawachi was recognized as the head temple of Jōbō Ritsu. In this denomination, however, monastics not only employed the SBR, but also studied the Uburitsu 有部律 (Konponsetsu issai ubu binaya 根本説一切有部毘奈耶, further: UBR, T. 1442) or the Mūlasarvastivādavinaya translated by Yijing 義淨 $(635-713)$ in the early $8^{\text {th }}$ century. ${ }^{7}$ (Ueda 1939: 123) Even though Jiun's Konponsetsu issai ubu esō ryakuyō 根本説一切有部依相略要 suggests that he envisaged establishing a samgha according to the UBR, he never argued for an exclusive reliance on it, nor did he reject the SBR as the foundation for the legitimate ordination procedure. (Ueda 1939: 127; For Jiun's vinaya sermons, see Watt 1992)

Although initially designed to revive the SBR, and therefore referred to as Dharmaguptaka branch (Shibunha 四分派), Edo period Shingon Risshū also developed a Mūlasarvāstivāda branch (Ubuha 有部派). (Ueda 1939: 141) This UBR movement started with Myōzui 妙瑞 (1696-1764), who was seventh in the Shinbessho, or Entsūji lineage on Kōyasan. Together with his disciples Mitsumon 密門 (d. 1788) of Shinbessho, Gakunyo 學如 (1716-1773; also Kakunyo) of Fukuōji 福王寺 in Aki 安藝 (modern-day Hiroshima), as well as Mitsumon’s disciple Tōkū 等空 (1745-1816) of Matsuoji 松尾寺 in Tango 丹後 (also Gotan 後丹), he

\footnotetext{
${ }^{7}$ The UBR is often ambiguously referred to as 有部律 Uburitsu, which can also point at the Chinese translation of the Sarvāstivādavinaya (Jüjuritsu 十誦律) or Ten Recitations Vinaya [T. 1435]. (Clarke 2006: 3, n. 4. For more information on the interpretation of the term 有部律 in this context, cf. Ueda 1932: 1-14; For a study of the Sankrit prātimokṣa of the Mūlasarvāstivādins, see Charles Prebish, Buddhist Monastic Discipline: The Sanskrit Prātimokṣa Sūtras of the Mahāsāmngikas and Mulasarvāstivādins (University Park, Pennsylvania: Pennsylvania State University Press, 1975). [Is full bibliographic reference needed here?]
}

PINTE Klaus, Shingon Risshū, version of Thursday, November 27, 2008, p. - 8 - 
claimed that Shingon adepts should uphold the UBR instead of - and not in addition to - the SBR, ${ }^{8}$ because Kūkai listed the UBR and not the SBR in the vinaya section (ritsubu 律部) of his Sangakuroku 三學録 or 'Catalogue of [Texts Consisting of] the Three [Divisions of] Learning'.9 Mitsumon, for instance, argued that since the precepts revival of the middle ages the SBR was employed instead of the UBR, which is counter to Kükai's teachings, and in his Shingon ritsugyō mondō 真言律行問答, Gakunyo pleaded to have a Shingon Risshū ordination system that was different from the one used in Risshū. (Ueda 1939: 125-128; For Myōzui, Mitsumon, Gakunyo and Tōkū, cf. Ueda 1939: 127-128 and Clarke 2006: 1-27, passim) In 1759, Gakunyo received permission from Ninnajimiya 仁和寺宮 to turn the Fukuōji on Kikisan 金鴑山 into a ‘Mūlasarvāstivādavinaya practice hall' (Uburitsu dōjōo 有部律道場) (Ueda 1939: 127).

\footnotetext{
${ }^{8}$ Although Mitsumon, Gakunyo and Tōkū's preaching of the UBR-revival is based on the teachings of Myōzui, it is important to note that Myōzui owed his preference for this vinaya to Shingen 眞源 (1689-1758) of Jōren'in 成蓮院 on Kōyasan. In 1756 Shingen recommended Jiun to write a revision on the Nankai kikiden 南海寄歸傳, i.e. Nankai kikiden geranshō 南海寄歸傳解纜鈔, finished at Fudōji 不動寺 in Nukata 額田 in 1758. Before his death, Shingen added an epilogue to Jiun's Ubu esō ryakuyō 有部依相略要, in which he argued for the exclusive implementation of the UBR. Therefore, Shingen, and not Myōzui can be considered as the actual founder of the UBR restoration movement. (Ueda 1939: 125-126; On Myōzui's biography, his inclination to the UBR and its related texts, see: Ueda 1939: 126-127; On Shingen, see: Mizuhara 1922; Inaya 1972)

${ }^{9}$ Full title: Shingonshū shogaku kyō-ritsu-ron mokuroku 眞言宗所學經律論目録 (Catalogue of Sūtras, Vinayas, and Śāstras to be Studied in the Shingon School), compiled by Kūkai in 823 cf. KDZ, Vol. I: 105-22. Although the Shingon monastic curriculum outlined in this catalogue was meant to addend the standard works of the Nara schools, and not to replace them, the question of Kūkai's exclusion of the SBR, has yet to be systematically addressed.
}

PINTE Klaus, Shingon Risshū, version of Thursday, November 27, 2008, p. - 9 - 
Although Shinbessho used to employ the SBR, from Myōzui onwards, the UBR was enacted, and especially after Mitsumon's time, the latter came to rely exclusively on the UBR. Therefore, Shinbessho-Entsūji, Fukuōji and Matsuoji are called the 'three Mūlasarvāstivāda training temples' (Ubu no san sōbō 有部の三僧坊). These formed the operating base of the UBR revival movement (Uburitsu fukkō undō 有部律復興運動), which strove to make the UBR the only 'Shingon-vinaya' (Shingon-ritsu 真言律) in Japan. (Ueda 1939: 127; More on the UBR revival in the post-Edo period, cf. Clarke 2006: 29-39). The popularity of this movement resulted in heavy disputes between the Shibunha and Ubuha branches of Shingon Risshū over which vinaya was to be followed. (Ueda 1939: 132-141) Thus, the vinaya was "in no way peripheral, but in fact an integral part of the life of the [Edo period] Shingon monastic communities" (Clarke 2006: 39-40).

Eventually, Shingon Risshū was recognized as an independent school in 1895 (MD 1277c, s.v. Shingon Risshū), and still profiles itself as the 'orthodox school' (seitōha 正統派). (Ueda 1939: 142) According to a survey conducted in 1930, Shingon Risshū had 72 temples (ji’in 寺院), lead by one chief abbot (kanchō 管長), 35 male and 4 female chief priests (jūshoku 住職), 59 male and 5 female teachers (kyōshi 教師). The school had about 8,700 temple supporters (danto 檀徒), and over 618,000 lay adherents (shinto 信徒). (MD 1278a, s.v. Shingon Risshū). The Outline of Japanese Buddhism (Nippon Bukkyō yōran 日本仏教要覧) ${ }^{10}$ draws approximately the

\footnotetext{
${ }^{10}$ A non-commercialized ‘espèce de Vade-mecum' distributed by the Japanese Buddhist Alliance (Nihon Bukkyō Rengōkai 日本佛教聯合會) exclusively to the Chinese and Korean participants who attended the Congress on East Asian Buddhism (Tōa Bukkyō Daikai 東亜佛教大會) in October 1925. Hartmann 1937: 319-320) <does this mean it
}

PINTE Klaus, Shingon Risshū, version of Thursday, November 27, 2008, p. - 10 - 
same picture based on a survey conducted in 1923. (Hartmann 1937: 325) Compared to Shingon and Risshū, the Shingon Risshū of the early 1920's was statistically larger than Risshū in numbers of ordained priests, employees, temples, training facilities and adherents, but was still much smaller than the Shingonshū. Though still of some importance today, Shingon Risshū has become quite a peripheral denomination in contemporary Japan. ${ }^{11}$

The Shingon Risshū scriptural canon (shōden 聖典) includes the following major works: (1) the BMK; (2) Yogāāārabhūmi-śāstra-prātimokșa translated by Xuanzang 玄牀 (646-648) (Yuga kaihon 瑜伽戒本 or Yugashijiron kaihon 瑜伽師地論戒本) ${ }^{12}$ [T. 1579]; (3) Dharmaguptaka-prātimokșa (Shibun-kaihon 四分戒本) [T. 1429] (German transl. Hankó 2003: 17-81); (4) the three major vinaya commentaries (ritsu san daibu 律三大部) by Daoxuan ${ }^{13}$; (5) Mūlasarvāstivāda-prātimokșa-sūtra (Konponsetsu issai ubukai kyō 根本説一切有部戒經) [T. 1454] ; (6) MSV (cf. supra....); (7) STT (cf. ... supra); (8) Yoginsūtra (Yugikyō 瑜祇經) [T. was given away free to $\mathrm{Ch} \& \mathrm{~K}$ participants as a promotion? Yes, it does. One could think of it in a similar way of the folders the IABS participants received in Atlanta ;-)>

${ }^{11}$ For now, the author has no access to more recent data.

${ }^{12}$ Also called Bodhisattva-prātimokșa or Pusajieben 菩薩戒本, actually comprising of only the last part of the $40^{\text {th }}$ fascicle and the $41^{\text {st }}$ fascicle, i.e. T. 1579: 510c7ff. (Malalasekera 1972: 241b) The history of the prātimokșa in Japan remains the subject of future research.

${ }^{13}$ Sifenlü shanfan buque xingshi chao 四分律刪繁補閶行事鈔 [T. 1804] compiled ca. 628; revised in 636 (Johnston 2000: 359-361). The two other commentaries are Sifenlü biqiu hanzhu jieben 四分律比丘含注戒本 [T. 1806] and Sifenlü shanbu suiji jiemo 四分律刪補隨機羯磨 [T. 1808]. On Daoxuan, see e.g. McRae 2005.

PINTE Klaus, Shingon Risshū, version of Thursday, November 27, 2008, p. - 11 - 
867] ${ }^{14}$; (9) Recitation Sūtra (Ryakunenjukyō 要略念誦經; Full title: Daibirushana bussetsu yōryaku nenju kyō 大毘盧遮那佛說要略念誦經) [T. 850]; (10) Susiddhikāra-sūtra (Sushijikyō 蘇悉地經, also Shoshijikyō) [T. 893 $]^{15}$; and (11) the Treatise on Mahāyāna (Shakumakaenron 釋 摩訶衍論) [T. 1668 $]^{16}$. While the first four texts are major scriptures of the Risshū corpus, the latter six are part of the Shingon canon. (Hartmann 1937: 323-325)

\footnotetext{
${ }^{14}$ Full title: Jingangfeng luoge yiqie yujia yuqi jing; Kongōbu rōkaku issai yuga yugi kyō 金剛峯樓閣一切瑜伽瑜祇 經 or 'Sūtra of the Pavilion with the Vajra Peak and all its Yogas and Yogins', attributed to Vajrabodhi. For a full, annotated Dutch translation see: Vanden Broucke 1990, the English translation of which is forthcoming as Vanden Broucke, Pol and Pinte, Klaus (trans.). Yugikyō: The Scripture of All Yogas and Yogīs of the Vajra Peak Pavillion (planned for 2011); see also Goepper 1993 for an English translation of chapter 5.

${ }^{15}$ Cf. supra: K. Pinte “Śubhākarasiṃha”, China/Esoteric Buddhism during the Tang, B.3; Giebel 2001.

${ }^{16}$ Shi moheyan lun is a commentary on the East Asian composition of the Awakening of Faith (Daijokishinron 大乗 起信論) [T. 1666], attributed to Nāgārjuna ( $2^{\text {nd }}-3^{\text {rd }}$ century), but was composed between the $7^{\text {th }}$ and $8^{\text {th }}$ century in the Korean kingdom of Silla (Buswell 2007: 369-370, n 284).
}

PINTE Klaus, Shingon Risshū, version of Thursday, November 27, 2008, p. - 12 - 